\title{
The ideal concept of foreign banking in the banking system in Indonesia: Challenges and Expectations
}

\author{
Grace Henni Tampongangoy \\ Faculty of Law, Sam Ratulangi University, North Sulawesi, Indonesia
}

\begin{abstract}
Financial sector restructuring has been adopted in many countries to improve the stability of financial system. The approach of restructuring may be different for each country due to the country specific condition; such as macroeconomic fundamental, corporate sector structure, political climate, culture, and accounting system. The research was conducted using a normative-legal research method with using statute and case approaches. The results show that the ideal legal construction for foreign banks in the framework of realizing the national development goals is through the establishment of a law that regulates foreign banks comprehensively with clarity of terms and operational oversight of foreign banks. Hence, a foreign bank legal entity should be a limited liability company and established according to Indonesian law so that supervision can be carried out in its position as a subsidiary in the context of investment in Indonesia.
\end{abstract}

Keywords: Bank; Banking System; Domestic Banks; Foreign Banks

DOI: $10.7176 / \mathrm{EJBM} / 11-19-07$

Publication date:July $31^{\text {st }} 2019$

\section{Introduction}

Foreign investment is one source of funds for national development. However, on the contrary, against foreign investment, the Investment Law in Indonesia provides certain restrictions as an effort to control foreign investment activities. Article 12 paragraph (1) of the Investment Law affirms that all business fields or types of businesses are open to investment activities except for types of businesses that are declared closed and open with certain conditions. Foreign investment is needed for the achievement of the goals and priorities of economic development policies, but simultaneously, is carried out by preventing the occurrence of dominance and the negative impact of foreign investment in the national economy. Hence, the Investment Law provides guidelines and certainty for investors, including foreign investors, but while maintaining and protecting the interests of the people of Indonesia and the national interests of the Republic of Indonesia.

Financial sector restructuring has been adopted in many countries to improve the stability of financial system, especially in the period of post crisis. ${ }^{1}$ The approach of restructuring may be different for each country due to the country specific condition; such as macro-economic fundamental, corporate sector structure, political climate, culture, and accounting system. ${ }^{2}$ The capital needed for the implementation of development can be provided by the government and by the community, especially the private sector.

The relationship occurs because each party needs each other in meeting their needs and interests. One of the business sectors that is allowed to invest in Indonesia, both domestic investment and foreign investment, is the banking business. Banks are financial institutions that have an essential role in the economy of a country. The main function of the bank is to collect and channel funds to the public or it can be said that the bank is an intermediary institution that bridges the party with excess funds which is then channeled to those who lack funds. In this case, banks play a very dominant role in contributing to Indonesia's national development.

An ideal situation is that capital needs can be fully met by the ability of capital in their own country. As it turns out into practice, in every developing country, the availability of capital for development as a whole is experiencing difficulties and to overcome it, one of the sources of funding for the state is through foreign investment. ${ }^{3}$ Foreign investment can provide benefits both directly and indirectly. Directly, foreign investment will provide additional

\footnotetext{
${ }^{1}$ Nasution, A. (1998). 'Big Bang'versus 'Go Slow': Indonesia and Malaysia. In Financial reform in developing countries (pp. 245-295). Palgrave Macmillan, London.

${ }^{2}$ Aznam, S. (1992). Away from the wheel: Shares in Indonesia's Astra sold as bank totters. Far Eastern Economic Review, 155, 63-63.

${ }^{3}$ Ilmar, A. (2004). Hukum Penanaman Modal di Indonesia. Jakarta: Prenada Media. p. 102
} 
funding for development and indirectly it can increase productivity and economic growth because through business processes, systems, management practices and new technologies, as well as a media link to export markets and supply chains internationally.

Governments always adjust banking policy and regulation to improve the stability and the effectiveness of financial system to respond the development of the financial industry. The adjustment may affect the structure of banking industry due to the adjustment of banks' policy to be fit with new rules and regulations. Restructuring is the best term to replace the adjustment of government policy and regulation in financial industry. The establishment of a mixed bank is a foreign investment as referred to in the Investment Law which is direct investment. Foreign participation in banking in Indonesia is not only in the form of foreign ownership in Indonesian banks but it can also be through the establishment of a foreign bank in the status of a branch office or even a representative office with a head office in the country of origin. ${ }^{4}$

The description above shows that foreign investment is needed for the achievement of the goals and priorities of economic development policies. ${ }^{5}$ Judging from the legal culture, the existence of foreign banks in Indonesia will discuss the relationship between foreign banks and efforts to achieve prosperity. The main key in the welfare state is the issue of guaranteeing people's welfare by the state. Regarding this, nowadays the guarantee of the welfare of the entire people is the main thing for a modern country.

\section{Method of the Research}

The research was conducted using a normative-legal research method with using statute and case approaches. It focuses on the study of the ideal concept of foreign banking in the Indonesian banking system.

\section{The Ideal Banking System in Managing Foreign Banks}

Banking institutions are one of the legal subjects in international trade so that in international trade traffic, banking institutions are subject to the rules of international trade law. Banking institutions have strategic values in the economy of a country. The institution is intended as an intermediary for parties who have excess funds with those who lack of funds. Hence, banks will move in credit activities, and various services provided.

As early as 1967, the Government of Indonesia started its liberalization program by enacting its Investment Law No. 1. In subsequent years, Indonesia has experienced rapid economic growth rate with amounted to around $7.3 \%$ over the period 1970-1996. Unfortunately, the 1997-8 economic crisis resulted in net private capital outflows from Indonesia. Data from Bank Indonesia presents negative foreign direct investment, on average about US\$ 3 billion for each year over the period 1998-2002. ${ }^{6}$

During the past two decades, foreign direct investment (FDI) has become increasingly important in the developing world, with a growing number of developing countries succeeding in attracting substantial and rising amounts of inward FDI. Economic theory has identified a number of channels through which FDI inflows may be beneficial to the host economy. Yet, the empirical literature has lagged behind and has had more trouble identifying these advantages in practice.

In 2017, there were 40 banks owned by foreign banks in Indonesia. The description above shows that basically the presence of foreign in the banking system in Indonesia can be seen in 3 (three) forms, namely the establishment of a branch or representative office, the establishment of a new bank, and the purchase of shares in an existing bank. The existence of foreign banks in Indonesia is developing related to business and investment needs, where Indonesia is very need foreign capital but the presence of foreign banks in Indonesia from a legal perspective continues to experience problems.

The present paper investigates the impact of being politically connected banks on performance and cost of funding. Going deeper, we look at the difference effect of political connections of foreign and private banks. ${ }^{7}$ Arguably, the value of political connections of foreign banks is less than that of domestic banks. Foreign banks' presence in a

\footnotetext{
${ }^{4}$ Supriyanto, E.B. (2018). Menyoal Kepemilikan Bank. KOMPAS, Tuesday, 21 June 2018.

${ }^{5}$ Irwansyah., Hakim. W., and Yunus, A. (2017).“Environmental Audit as Instrument for Environmental Protection and Management". The Business and Management Review, 9(2), 228-232

${ }^{6}$ Khaliq, A., \& Noy, I. (2007). Foreign direct investment and economic growth: Empirical evidence from sectoral data in Indonesia. Journal of Economic Literature, 45(1), 313-325.

7 Sutopo, B., Trinugroho, I., \& Damayanti, S. M. (2017). Politically connected banks: Some Indonesian evidence. International Journal of Business and Society, 18(1), 83-94.
} 
developing country is expected to bring favorable economic impacts to the host country as they have better hard information and technology which lead them to perform more efficiently in their business.

Overall, the findings support hypothesis that political connections improve bank accounting performance. Interestingly, this evidence is confirmed by the other finding that politically connected banks have lower cost of funding than that of non-politically connected banks. It means that the higher performance of politically connected banks is driven by lower cost of funding which ultimately could lead to higher interest margins. Moreover, our results on the difference effect of political connections between foreign and private banks confirm our hypothesis. These kinds of connections are less beneficial for foreign banks as they have another source of competitive advantage to participate in emerging markets.

Determination of policies taken by bank management is strongly influenced by the owners, so that even though a commercial bank is established according to Indonesian law but if the capital structure includes a majority of foreigners, then all bank policies will be influenced by those whose ownership is more dominant. It is different if ownership is carried out by foreigners only in the ownership of shares. For ownership due to share purchase, controlling the management of the company is not the goal of the shareholders, but obtaining profits from the purchase of shares is the main goal. Every policy that will be taken by the management is always influenced by the wishes of its shareholders. This is what causes the greater public share ownership, the greater the control mechanism for managing behavior.

The existence of a composition of public shareholders will facilitate monitoring, intervention, or some other influence of discipline on managers, which in turn will make managers act in the interests of shareholders. The composition of public shareholders will also influence the ownership of directors as well as the commissioners' company. In other words, the increase in public shareholders will also be accompanied by the increasing selection of boards from outside, which in turn will affect the company's performance. Also, this view is reinforced by the existence of 'one share one vote principle' in limited company rules.

The results show that the majority ownership of shares in a commercial bank by a foreign party in the view of the researcher does not necessarily cause the commercial bank to become a foreign bank. However, the composition of share ownership will change at any time according to purchases on the stock exchange. Hence, the ownership of shares by foreigners in a commercial bank in the view of the researcher is not a measure to state that the bank has become a foreign bank. Thus, the definition of a foreign bank must be clarified in terms of the law used when it was established, the owner of the owner seen from the structure of the capital placed and not from ownership due to the purchase of shares (Table 1).

Table 1. Data on differences in regulation of foreign banks in Indonesia and other countries.

\begin{tabular}{|c|c|c|}
\hline No & Country & Banking Regulation \\
\hline 1 & Indonesia & $\begin{array}{l}\text { - } \quad \text { By buying a private bank, foreign banks are free to open a branch office. } \\
\text { - } \quad \text { ATM outlets are unlimited. } \\
\text { - } \quad \text { Minimum capital of Rp. } 3 \text { trillion is only for the establishment of a new bank. } \\
\text { - } \quad \text { Foreign ownership in local banks is permitted up to } 99 \% \text {. }\end{array}$ \\
\hline 2 & Malaysia & $\begin{array}{l}\text { - Maximum } 12 \text { branch banks ( } 2 \text { in big cities, } 4 \text { in suburbs, and } 6 \text { in rural areas). } \\
\text { - Not allowed to place ATMs outside the branch office area. } \\
\text { - Minimum capital requirements of RM } 300 \text { million (US } \$ 100 \text { million). } \\
\text { - Ownership at a local bank: For individual maximum } 20 \% \text {, for institution } \\
\text { maximum } 30 \% \text {. }\end{array}$ \\
\hline 3 & Singapore & $\begin{array}{l}\text { - Operating licenses are given in stages (full bank, wholesale bank, offshore bank, } \\
\text { and merchant bank). } \\
\text { - Opening of branch offices and ATMs is limited. } \\
\text { - } \quad \text { Maximum foreign ownership at a local bank } 20 \% \text {. }\end{array}$ \\
\hline 4 & Vietnam & - Maximum foreign ownership at a local bank is $30 \%$ \\
\hline 5 & India & - $\quad$ Maximum foreign ownership at a local bank $49 \%$. \\
\hline 6 & USA & $\begin{array}{l}\text { - Maximum foreign ownership at a local bank 25, with a maximum controlling } \\
\text { share limit of } 10 \% \text {. }\end{array}$ \\
\hline
\end{tabular}

Source: Primary data, edited 2019

Table 1 shows that in other countries, the foreign ownership limit is set to very minimal, which does not reach $50 \%$, even in other countries, foreign ownership also limits stock ownership in the stock and $100 \%$ of shares are allowed to divest shares up to $51 \%$ every 10 years. This is due to the presence of banks, one of which is useful for 
collecting funds directly from the community and channeling it back to the community through credit law institutions. In addition, banking institutions as the main source of financing are obliged to facilitate the development of the market economy.

By looking at these conditions, the potential for legal conflicts arises. The bank's subsidiaries basically have independence, so in the relationship between the parent company and its subsidiaries, each party has independence that can be a protection for the parent company and its subsidiaries. The parent company as a shareholder is only responsible for the value of its shares in the subsidiary company and even though there is control by the parent company but may not exercise excessive control.

Foreign banks that can operate in Indonesia are banks that are branch offices and representative offices of foreign banks so that all foreign banks have control of the company in the hands of the parent company including the legal entity form following the legal entity of the parent company. This led to the existence of non-independence from the status of the branch office. In contrast, this will be different if the form of a foreign bank in Indonesia is formed in relation to being an independent subsidiary and the form of the legal entity is a limited liability company as stipulated in the Investment Law.

capital in driving development and economic growth. Foreign banks are very important in moving foreign exchange and stabilizing the rupiah exchange rate but the presence of foreign banks in Indonesia is still vulnerable to the emergence of problems, especially in relation to the position of banks as an intermediary institution in national economic growth. ${ }^{8}$ Foreign banks are very easy to established and obtain facilities, while Indonesian banks are very difficult to be established in other countries. Likewise, in investment in the form of shares, Indonesian rules provide a maximum limit of 99 percent of foreign ownership while in other countries, the maximum limit of foreign ownership is only 45 percent, such as in Singapore and Malaysia.

The discourse to require foreign bank branch offices for limited liability companies has been discussed in the drafting of the banking law, but this discourse still raises debate (Results of interviews with the Indonesian Financial Services Authority). This debate is related to differences of opinion regarding the status of foreign bank legal entities. Some parties are of the view that with a limited liability company, all activities of the foreign bank are subject to Indonesian law and have independence in their business activities and the condition of the parent company will not affect subsidiaries in Indonesia.

The parent company will no longer provide facilities as if the position is a branch office and this will cause the development of foreign banks in Indonesia to experience a setback due to difficulties in making preparations in Indonesia. As a result, if a foreign bank company in the form of a Limited Liability Company has liquidity difficulties, the parent company does not necessarily help its subsidiary because it is legally separate from the parent company. Responding to changes in legal entities of foreign banks to become limited liability companies as stipulated in the Investment Law, researchers believe that a law is formed to be implemented. For this reason, a rule is made of course already based on philosophical, juridical and sociological considerations and when the Law Investment provides a mandatory form of a limited liability company as a form of legal entity.

Nevertheless, regulation of the form of a business entity towards the implementation of foreign investment is an order from the Investment Law, which aims to provide legal certainty to every investment in Indonesia. This is nothing but aiming for investments that are part of the implementation of the national economy to be placed as an effort to increase national economic growth, create jobs, improve sustainable economic development, increase national technological capacity and capabilities, encourage the development of populist economics, and realize public welfare in a competitive financial system.

\section{Conclusion}

The ideal legal construction for foreign banks in the framework of realizing the national development goals is through the establishment of a law that regulates foreign banks comprehensively with clarity of terms and operational oversight of foreign banks. The reality of the Branch Offices of foreign banks in Indonesia currently still follows the legal entity of their home country, so supervision is carried out by the Indonesian Investment Coordinating Board. The supervision of the Financial Services Authority on foreign banks can be carried out if the existence of the bank is not in the context of investment and if the licensing is by the Investment Coordinating Board, all oversight is within the authority of the Investment Coordinating Board. Finally, a foreign bank legal entity should be a limited liability company and established according to Indonesian law so that supervision can be carried out in its position as a subsidiary in the context of investment in Indonesia.

\footnotetext{
${ }^{8}$ Atmasasmita, R. (2010). Globalisasi Kejahatan Bisnis. $2^{\text {nd }}$ edition. Jakarta: Prenada Media. p.53
} 


\section{References}

Atmasasmita, R. (2010). Globalisasi Kejahatan Bisnis. $2^{\text {nd }}$ edition. Jakarta: Prenada Media. p.53

Aznam, S. (1992). Away from the wheel: Shares in Indonesia's Astra sold as bank totters. Far Eastern Economic Review, 155, 63-63.

Ilmar, A. (2004). Hukum Penanaman Modal di Indonesia. Jakarta: Prenada Media. p. 102

Irwansyah., Hakim. W., and Yunus, A. (2017).“Environmental Audit as Instrument for Environmental Protection and Management". The Business and Management Review, 9(2), 228-232

Khaliq, A., \& Noy, I. (2007). Foreign direct investment and economic growth: Empirical evidence from sectoral data in Indonesia. Journal of Economic Literature, 45(1), 313-325.

Nasution, A. (1998). 'Big Bang’versus 'Go Slow': Indonesia and Malaysia. In Financial reform in developing countries (pp. 245-295). Palgrave Macmillan, London.

Supriyanto, E.B. (2018). Menyoal Kepemilikan Bank. KOMPAS, Tuesday, 21 June 2018.

Sutopo, B., Trinugroho, I., \& Damayanti, S. M. (2017). Politically connected banks: Some Indonesian evidence. International Journal of Business and Society, 18(1), 83-94. 